\title{
ANALISIS KONFLIK JALAN SEBAGAI RUANG PUBLIK PERKOTAAN (STUDI KASUS : JALAN LINGKUNGAN MENUJU DANAU MAWANG, KABUPATEN GOWA)
}

\author{
Sriany Ersina*1 \\ Universitas Islam Negeri Alauddin Makassar \\ $e$-mail: *1 sriany.ersina@uin-alauddin.ac.id
}

\begin{abstract}
Abstrak_ Ruang publik yang ideal harus menjadi landasan bersama, terbuka dan dapat diakses untuk semua, termasuk bagi para penyandang cacat. Namun kenyataannya, di sepanjang jalan lingkungan menuju Danau Mawang tidak semua ruang publik yang dapat diakses. Idealnya, berbagai orang yang menggunakan dan melakukan interaksi di ruang publik harus diakomodasi dalam ruang. Potensi konflik ada kapan saja dan di mana pun orang-orang berinteraksi. Konflik bersifat wajar, normal, dan tidak dapat dihindari setiap kali orang berinteraksi bersama. Ketidaksepakatan dan perbedaan pada konflik nilai dapat diindikasikan oleh situasi tak terhindarkan dalam hubungan manusia. Oleh karena itu, mendefinisikan perbedaan dan strategi untuk mengelola konflik di ruang publik akan menjadi fokus dari penelitian ini. Sinergi, kompromi, tindakan akomodatif dan penggunaan kekuatan antara lain adalah strategi mengelola konflik untuk menciptakan lingkungan yang dibangun menuju tempat umum yang terbuka dan dapat diakses.

Ruang publik adalah tempat bersama di mana orang melakukan kegiatan fungsional dan ritual yang mengikat komunitas, baik dalam rutinitas normal kehidupan sehari-hari atau dalam perayaan periodik (Bishop dan Krik R. 1989). Jalan Perkotaan yang berhubungan dengan sebagian besar ruang publik harus melayani masyarakat luas, masyarakat majemuk dan berbagai perilaku manusia.

Dalam penelitian ini berlandaskan pada paradigma rasionalitik dengan pendekatan metode penelitian deskriptif yaitu; studi pustaka tentang teori dasar ruang publik perkotaan, observasi lapangan, dan menganalisis data dengan menggunakan ArchGIS program (program pemetaan digitalisasi).

Dengan mengelola konflik di sepanjang Jalan Lingkungan menuju Danau Mawang sebagai ruang publik perkotaan sebaik mungkin akan dapat menciptakan ruang publik yang terbuka dan dapat diakses dengan baik oleh seluruh masyarakat setempat.
\end{abstract}

Kata kunci : Ruang Publik; Konflik Ruang Publik; Jalan Perkotaan.

\footnotetext{
${ }^{1}$ Universitas Islam Negeri Alauddin Makassar
} 


\section{PENDAHULUAN}

Jalan kota adalah ruang publik yang merupakan tempat bersama di mana orang melakukan kegiatan fungsional dan ritual yang mengikat komunitas, baik dalam rutinitas normal kehidupan sehari-hari atau dalam perayaan periodik.

Desain perkotaan, yang berhubungan dengan sebagian besar ruang publik harus melayani masyarakat luas, masyarakat majemuk (Shirvani, Hamid. (1985) dan berbagai perilaku manusia (Kornblum, William. 1979). Sangat penting untuk tujuan kita bahwa lingkungan masa depan menjadi satu kesatuan yang terbuka dimana individu dapat dengan mudah mengaksesnya, dan di mana ia dapat bertindak dengan pilihannya sendiri (Banerjee, Tridib and Michael Southworth. 1990). Pada prinsipnya, penciptaan jalan sebagai ruang publik harus mempertimbangkan karakternya sebagai landasan bersama untuk berbagai aktivitas orang, lingkungan terbuka dengan kebebasan untuk digunakan, dan dapat diakses untuk semua termasuk bagi para penyandang cacat. Kebebasan untuk menggunakan ruang publik menunjukkan adanya "peraturan tidak tertulis" yang bergantung pada sikap, perilaku dan kebutuhan untuk orang lain. Tidak ada dominasi individu atau kelompok atas yang lain. Harus ada keadilan untuk memasyarakatkan jalan sebagai ruang publik.

\section{Perubahan kepemilikan domain publik:}

Meskipun Dumouchel dan J.Robert (1975) mendefinisikan bahwa tanah yang dimiliki oleh pemerintah adalah domain publik, orang saat ini dapat menemukan bahwa tanah milik pribadi juga terbuka dan dapat diakses oleh publik. Pergeseran terjadi ketika otoritas atas tanah telah meyakinkan pemilik pribadi untuk keberhasilan kontrol tanah jika tanah itu digunakan publik.

\section{Perubahan batasan ruang:}

Hingga abad ke-19 beberapa gedung dibuka untuk umum. Ruang publik yang sebenarnya hampir selalu di luar pintu. Bangunan-bangunan umum (Hertsberger, Herman, 1991) Ada pergeseran pada karakter ruang lingkup gedung publik tersebut. Dari ruang terbuka ke ruang bangunan. Perubahan persepsi pemilik tanah pribadi untuk melayani masyarakat luas membuat lebih banyak bangunan publik dibangun. Pusat perbelanjaan dan berbagai museum yang dimiliki oleh swasta adalah salah satu contoh bangunan publik.

\section{Perubahan karakter ruang:}

Bentukan tradisional sangat erat diidentifikasi dengan tujuan seperti menampilkan kekuatan politik atau melayani sebagai tempat untuk perdagangan. Saat ini banyak alun-alun, jalan, ataupun tepian jalan sering dengan terpaksa digunakan sebagai tujuan khusus selain untuk memberikan pesona atau tempat pertemuan yang menyenangkan (Asensio Cerver dan Fransisco, 1997). Ada indikasi pergeseran untuk menunjukkan kekuatan politik (karakter tradisional dan monumental), atau lebih dari untuk mengakomodasi kebutuhan masyarakat tradisional (karakter organik seperti pasar tradisional, dan jalan-jalan lingkungan perkotaan) ke tujuan yang lebih modern dan dinamis. Kecenderungan daerah perkotaan untuk membangun infrastruktur jalan tanpa memikirkan sesuatu yang lebih manusiawi, dalam hal ini harusnya lebih menarik dan sebagai rekreasi yang bisa menunjukkan salah satu bukti perubahan dan usaha dalam upaya memperbaiki ruang publik 
perkotaan dengan karakteristiknya. Seperti halnya jalan lingkungan menuju Danau Mawang, Kabupaten Gowa yang dibangun berdasarkan kepentingan - kepentingan oknum tertentu saja, sehingga seringkali terjadi konflik dalam penggunaannya oleh masyarakat setempat. Di sepanjang jalan lingkungan menuju Danau Mawang tidak semua ruang publik yang dapat diakses. Idealnya, berbagai orang yang menggunakan dan melakukan interaksi di ruang publik harus diakomodasi dalam ruang. Potensi konflik ada kapan saja dan di mana pun orang-orang berinteraksi. Konflik bersifat wajar, normal, dan tidak dapat dihindari setiap kali orang berinteraksi bersama. Ketidaksepakatan dan perbedaan pada konflik nilai dapat diindikasikan oleh situasi tak terhindarkan dalam hubungan manusia. Oleh karena itu, mendefinisikan perbedaan dan strategi untuk mengelola konflik di ruang publik akan menjadi fokus dari penelitian ini. Sinergi, kompromi, tindakan akomodatif dan penggunaan kekuatan antara lain adalah strategi mengelola konflik untuk menciptakan lingkungan yang dibangun menuju tempat umum yang terbuka dan dapat diakses. Oleh karena itu dalam kajian ini diharapkan dapat memberi solusi terhadap jalan lingkungan menuju Danau Mawang, Kabupaten Gowa.

Dalam penelitian ini berlandaskan pada paradigma rasionalitik dengan pendekatan metode penelitian deskriptif yaitu studi pustaka tentang teori dasar ruang publik perkotaan, observasi lapangan, dan menganalisis data dengan menggunakan ArchGIS program (program pemetaan digitalisasi).

Dengan mengelola konflik di sepanjang Jalan Lingkungan menuju Danau Mawang sebagai ruang publik perkotaan sebaik mungkin akan dapat menciptakan ruang publik yang terbuka dan dapat diakses dengan baik oleh seluruh masyarakat setempat.

\section{METODE}

Metodologi penelitian dapat dilihat sebagai teknik yang digunakan untuk mengumpulkan dan menganalisis data. Data yang dikumpulkan harus terkait dengan tujuan dan pernyataan masalah. Ada dua jenis metode yang digunakan dalam penelitian ini untuk memperoleh data yang relevan yaitu tinjauan pustaka dan observasi.

Adapun waktu observasi dilakukan hanya pada siang sampai dengan sore harinya dari hari Senin sampai dengan Minggu, antara jam 11.00 - 16.00 WITA, konstan di sepanjang Jalan Lingkungan menuju Danau Mawang, Kabupaten Gowa.

Observasi dilakukan di sepanjang jalan lingkungan menuju Danau Mawang. Observasi dilakukan dengan menggunakan instrument kamera smartphone, dan pengambilan foto tersebut untuk tujuan memberikan bukti yang kuat untuk mendukung hasil penelitian. Serta menganalisis data dengan menggunakan ArchGIS program (program pemetaan digitalisasi). 


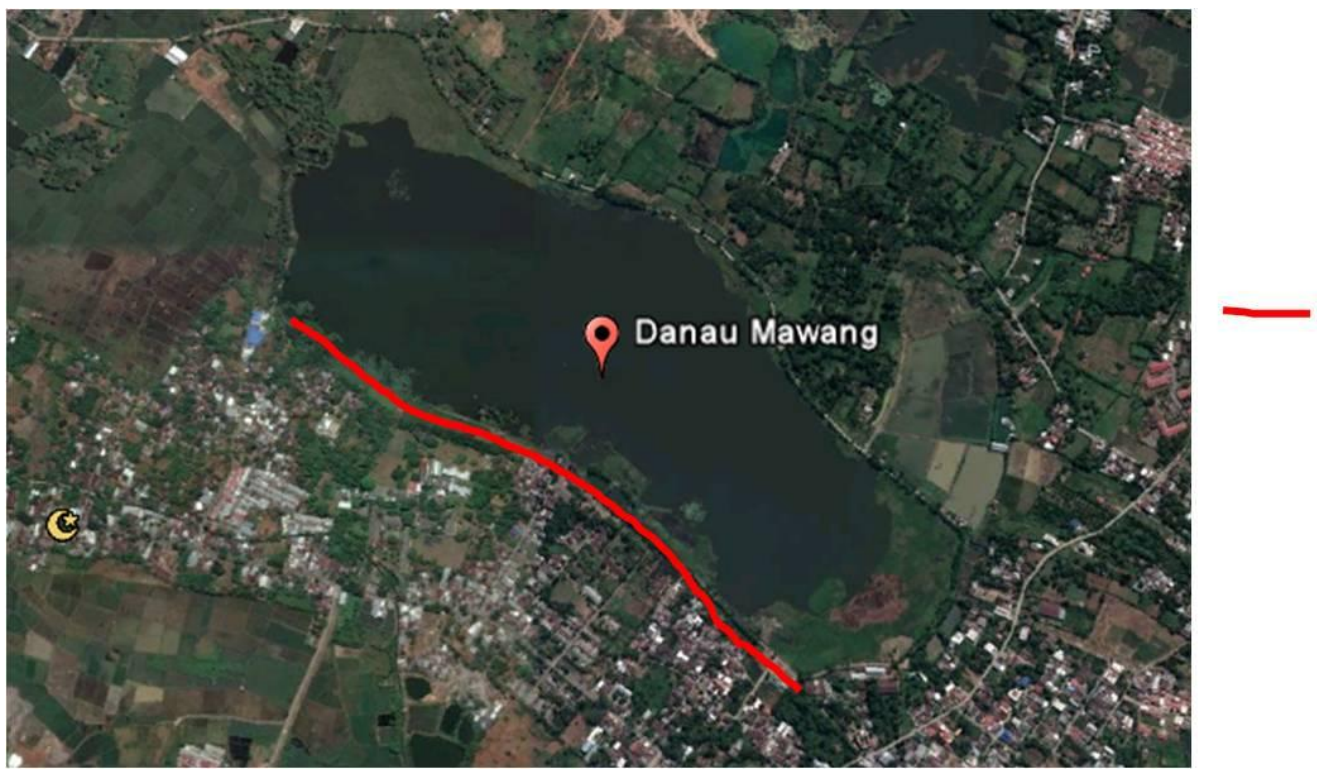

Keterangan :

JALAN LINGKUNGAN MENUJU DANAU MAWANG, KABUPAIENGOWA

+/-1.215 meter (panjang jalan)

Gambar 1 : Peta Jalan Lingkungan Menuju Danau Mawang, Kabupaten Gowa.

(Sumber: Analisa Penulis, 2018)

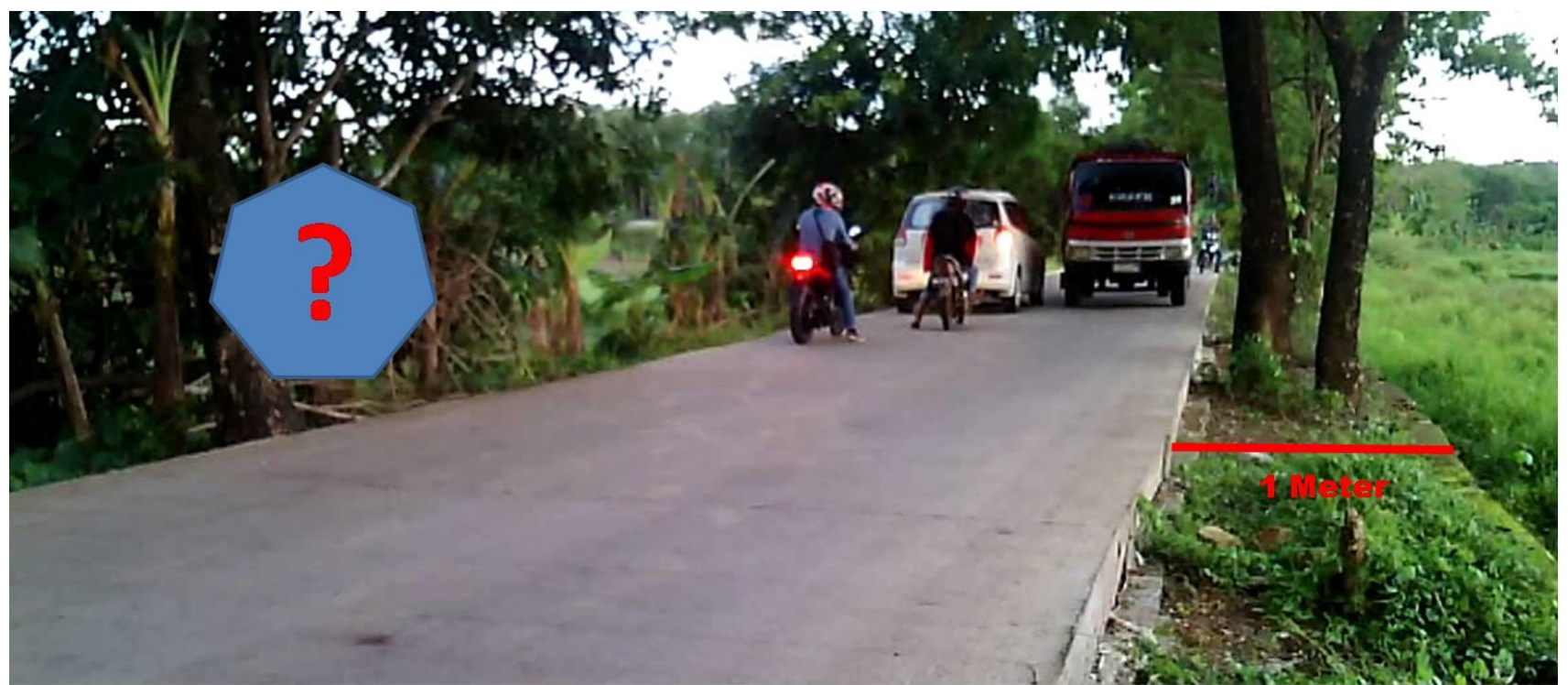

Gambar 2 : Sepanjang Jalan Lingkungan Menuju Danau Mawang, Kabupaten Gowa. (Sumber: Analisa Penulis, 2018) 


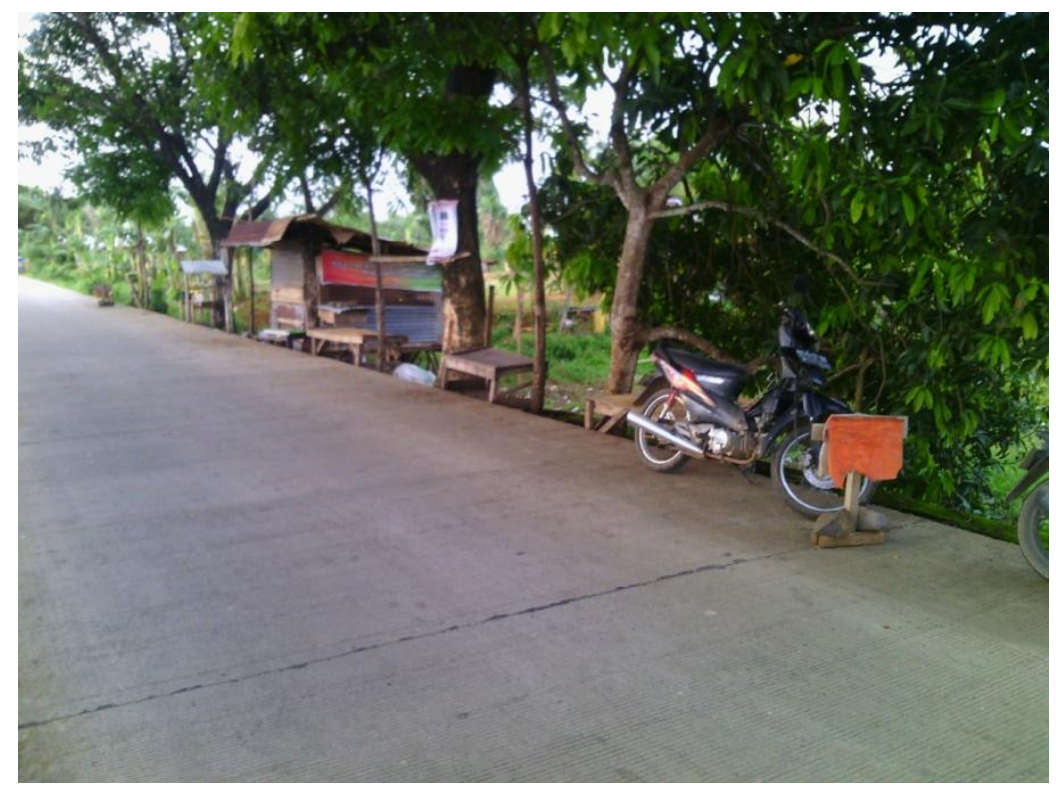

Gambar 3 : Sepanjang Jalan Lingkungan Menuju Danau Mawang, Kabupaten Gowa. (Sumber: Analisa Penulis, 2018)

Konflik bersifat alami, normal, dan tak terhindarkan kapan pun orang berinteraksi bersama (Lingren, Herbert G. 1996). Konflik adalah pembedaan alami yang dihasilkan dari individu atau kelompok yang berbeda dalam kebutuhan, persepsi, perasaan, emosi, sikap, nilai, keyakinan, atau kekuatan (Hoban, Thomas J. 2004). Konflik di ruang publik di sepanjang jalan menuju Danau Mawang, Kabupaten Gowa, muncul:

1. Ketika satu atau kelompok mengabaikan kebutuhan orang lain.

Kota-kota sekarang, khususnya di Kabupaten Gowa sebagian besar tidak dapat diakses. Banyak jalan telah dirancang dan direncanakan oleh apa yang disebut sebagai "perancang dan perencana kota yang normal, muda-dewasa, dan relatif kaya". Mereka lupa bahwa jalan sebagai ruang publik perkotaan hidup oleh berbagai orang di dalamnya, mereka secara subjektif berpikir hanya penting untuk kebutuhan mereka. Akibatnya, kota jarang atau tidak pernah ramah kepada anak-anak, orang-orang cacat, berpenghasilan rendah, serta kaum wanita. (Lihat Gambar 2)

2. Ketika orang menafsirkan realitas secara berbeda.

Orang mungkin memiliki persepsi atau perspektif yang berbeda untuk melihat masalah yang ada di sepanjang jalan lingkungan menuju Danau Mawang. Dari perspektif pengguna pejalan kaki seperti pengguna kursi roda, orang buta, keluarga, anak-anak dan turis, para pedagang atau dikenal sebagai kaki lima benar-benar mengganggu jalan mereka melewati pejalan kaki, apalagi tampak jelas tidak terdapat jalur pejalan kaki di sepanjang jalan tersebut. Dari perspektif pedagang, jalur pejalan kaki adalah tempat umum di mana semua orang memiliki hak untuk menggunakannya termasuk untuk berbisnis. Dari perspektif otoritas, tidak ada aspek hukum yang mengatur sektor informal seperti kaki lima melakukan perdagangan di sepanjang jalan sebagai ruang publik. (Lihat Gambar 3) 


\section{HASIL DAN PEMBAHASAN}

Data yang dikumpulkan dari observasi akan dianalisis dan dibahas.

\section{A. Kondisi Jalan Lingkungan Menuju Danau Mawang, Kabupaten Gowa}

Sepanjang pengamatan, jalan lingkungan menuju Danau Mawang, Kabupaten Gowa hanya dapat digunakan oleh kendaraan bermotor maupun mobil, dan jalur pejalan kaki yang memang tidak ada digunakan oleh sektor informal seperti kaki lima melakukan perdagangan.

\section{B. Analisis mengelola Konflik di Sepanjang Jalan sebagai Ruang Publik}

Konflik tidak selalu negatif. Ketidaksepakatan perbedaan atau konflik nilai di atas dapat diindikasikan oleh situasi tak terhindarkan dalam hubungan manusia (Lingren, Herbert G. 1996). Bahkan, itu bisa "sehat" ketika dikelola secara efektif. Konflik yang sehat dapat menyebabkan pertumbuhan dan inovasi, cara-cara berpikir baru dan pilihan manajemen tambahan. Jika konflik dipahami, itu dapat dikelola secara efektif dengan mencapai konsensus yang memenuhi kebutuhan individu dan masyarakat. Ini menghasilkan saling menguntungkan dan memperkuat hubungan (Hoban, Thomas J. 2004).

Menurut Lingren, Herbert G. (1996), ada lima strategi luas yang biasanya digunakan orangorang dalam berurusan dengan ketidaksetujuan dan kekuatan konflik, kompromi, menarikhindari, menenangkan hasil, dan bersinergi. Demikian pula, Hoban, Thomas J. (2004), mengkategorikan strategi manajemen konflik menjadi kolaborasi, kompromi, persaingan, akomodasi, dan penghindaran. Dalam beberapa kasus, mungkin perlu memiliki fasilitator netral untuk membantu memindahkan kelompok / individu yang mengalami konflik ke arah konsensus.

Solusi; win-win - I Win, You Win (win-win solution), adalah pendekatan sinergis yang melekat pada kedua tujuan dari pihak-pihak yang berkonflik. Keduanya dengan antusias bekerja sama untuk mencapai konsensus. Kompromi "Saya menang (sedikit), Anda menang (sedikit)", adalah resolusi yang dinegosiasikan sebagai sarana untuk membuat solusi lebih dapat ditolerir oleh masing-masing pihak. Karena pengguna ruang publik memiliki berbagai kegiatan, tujuan, dan sikap, mereka harus mentoleransi minat untuk pihak lain, dan berusaha untuk melayani "kebaikan bersama".

Sebagai pendekatan akomodatif dengan membuat situasi pada "Saya kalah, Anda menang" adalah cara efektif untuk melindungi diri dan melindungi hubungan Anda dengan orang lain. Strategi ini umumnya digunakan ketika masalah lebih penting bagi orang lain, atau orang mencoba untuk menghindari konflik dengan kebutuhan orang lain. Strategi "Saya menang, Anda kalah" dihasilkan dari kepedulian yang tinggi terhadap kepentingan kelompok dengan kurang memperhatikan pihak lain. Strategi melibatkan resolusi dengan menggunakan kekuatan dan memenangkan kekuatan atau paksaan. Ini umumnya digunakan ketika hak-hak dasar terancam.

Sementara itu, pendekatan untuk mencapai strategi tanpa harapan "Saya kalah, Anda kalah" menunjukkan upaya untuk melindungi pihak-pihak yang terlibat konflik dari terjebak dalam perjuangan tanpa henti yang tidak dapat dimenangkan. Pendekatan penghindaran ini digunakan ketika konfrontasi memiliki potensi kerusakan yang tinggi.

Jalan secara konseptual didefinisikan sebagai "tempat untuk gerakan serta tempat untuk pertukaran dan untuk kontak publik" (Rapoport, Amos. 1987). Tipe jalan yang ideal harus 
mengakomodasi fungsi bergerak dan berbagi. Jalan harus menjadi tempat di mana semua orang termasuk penyandang cacat bisa melewatinya dengan mudah, tetapi pada saat yang sama juga memberi mereka kemungkinan untuk berinteraksi secara sosial (dengan berhenti dan mengobrol dengan teman, bertindak untuk membuat ruang publik menjadi dapat ditinggali dan menyenangkan) untuk melakukan pertukaran secara ekonomi (seperti mengizinkan pedagang kaki lima dan musisi jalanan untuk melayani orang yang lewat), untuk melakukan kampanye dan mempromosikan konsep kelompok atau ideologi kepada publik. Tipe jalan yang ideal ini memungkinkan semua pengguna memiliki kebebasan untuk menggunakan ruang publik. Mereka semua adalah pemenang.

Terkadang konsep jalan dipahami bahwa "kekuatan rakyat" dari dimensi yang lain pula, yaitu; memaksa jalan hanya untuk mengoperasikan satu fungsi yaitu sebagai tempat untuk pertukaran ideologi politik. Dalam hal ini, otoritas lokal dapat menjadi salah satu kekuatan efektif untuk mengelola konflik dalam menggunakan ruang publik.

Ruang publik adalah tempat bersama di mana orang melakukan kegiatan fungsional dan ritual yang mengikat komunitas, baik dalam rutinitas normal kehidupan sehari-hari atau dalam perayaan periodik (Bishop, Krik R. 1989). Koridor perkotaan yang berhubungan dengan sebagian besar ruang publik harus melayani masyarakat luas, masyarakat majemuk dan berbagai perilaku manusia.

\section{KESIMPULAN}

Harus ada langkah-langkah untuk mengelola konflik di sepanjang Jalan Lingkungan menuju Danau Mawang sebagai ruang publik perkotaan. Kita harus mulai menganalisis konflik dengan memahami apa yang berbeda dari kebutuhan, nilai, persepsi, dari pihak-pihak yang terlibat yang menyebabkan konflik dalam menggunakan atau menciptakan ruang publik yang terbuka dan dapat diakses. Kemudian menentukan strategi manajemen dengan secara hati-hati mengembangkan pendekatan sinergis, kompromi, tindakan akomodatif, menggunakan pendekatan kekuasaan atau membiarkan konflik tidak terpecahkan. Ketika mengembangkan kriteria untuk memilih atau menggabungkan alternatif yang mungkin, kita harus meninjau kembali keinginan yang bertentangan. Itu juga harus mengingat prinsip-prinsip seperti keadilan, dan efisiensi. Pendekatan yang dipilih harus dinegosiasikan kepada semua pihak yang berkonflik sebelum implementasinya. Entah melalui proyek percontohan atau pengembangan total. Tujuan yang ingin dicapai tetap sebagai solusi menuju ruang publik yang lebih demokratis, terbuka dan dapat diakses.

\section{DAFTAR REFERENSI}

Asensio Cerver, Fransisco. (1997). Redesigning City Square and Plazas. New York: Herats Book International.

Banerjee, Tridib and Michael Southworth. (1990). City Sense and City Design. Cambridge: The MIT Press.

Bishop, Krik R. (1989). Designing Urban Corridors. Washington,DC: American Planning Association. Cooper M, Clare and Carolyn Francis. (1998). People Places. Design Guidelines for Urban Open Space.

2nd Edition. New York: Van Nostrand Reinhold Company.

Darmawan,E. (2005). Analisis Ruang Publik Arsitektur Kota. Badan Penerbit UNDIP, Semarang 
Dumouchel, J Robert. (1975). Dictionary of Development Terminology. New York: McGraw-Hill Book Company.

Hertsberger, Herman. (1991). Lesson for Students In Architecture. Rotterdam: Uitgeverij 010 Publishers.

Hoban, Thomas J. (2004). Managing Conflict. A Guide for Watershed Partnerships.

Kornblum, William. (1979). The Psychology of City Shape.In Urban Open Space. New York: Rizzoly International Publication.

Lingren, Herbert G. (1996). Managing Conflict Successfully.

Lynch, Kevin. (1992). Good City Form. Cambridge: MIT Press.

Rapoport, Amos. (1987) Pedestrian Street Use: Culture and Perception.,In Public Streets for Public Use. New York: Van Nostrand Reinhold Company.

Shirvani, Hamid. (1985). The Urban Design. Process. New York: Van Nostrand Reinhold Company. 